\title{
Universiteit
}

Leiden

The Netherlands

\section{Safeguarding pollinators and their values to human well-being}

Potts, S.G.; Imperatriz-Fonseca, V.; Ngo, H.T.; Aizen, M.A.; Biesmeijer, J.C.; Breeze, T.D.; ... ; Vanbergen, A.J.

\section{Citation}

Potts, S. G., Imperatriz-Fonseca, V., Ngo, H. T., Aizen, M. A., Biesmeijer, J. C., Breeze, T. D., ... Vanbergen, A. J. (2016). Safeguarding pollinators and their values to human wellbeing. Nature, 540, 220-229. doi:10.1038/nature20588

Version: Publisher's Version

License: $\quad$ Licensed under Article 25fa Copyright Act/Law (Amendment Taverne)

Downloaded from: https://hdl.handle.net/1887/3212781

Note: To cite this publication please use the final published version (if applicable). 


\section{Safeguarding pollinators and their values to human well-being}

Simon G. Potts ${ }^{1}$, Vera Imperatriz-Fonseca ${ }^{2}$, Hien T. Ngo ${ }^{3}$, Marcelo A. Aizen ${ }^{4}$, Jacobus C. Biesmeijer ${ }^{5,6}$, Thomas D. Breeze ${ }^{1}$, Lynn V. Dicks ${ }^{7}$, Lucas A. Garibaldi ${ }^{8}$, Rosemary Hill ${ }^{9}$, Josef Settele ${ }^{10,11}$ \& Adam J. Vanbergen ${ }^{12}$

Wild and managed pollinators provide a wide range of benefits to society in terms of contributions to food security, farmer and beekeeper livelihoods, social and cultural values, as well as the maintenance of wider biodiversity and ecosystem stability. Pollinators face numerous threats, including changes in land-use and management intensity, climate change, pesticides and genetically modified crops, pollinator management and pathogens, and invasive alien species. There are well-documented declines in some wild and managed pollinators in several regions of the world. However, many effective policy and management responses can be implemented to safeguard pollinators and sustain pollination services.

$\mathrm{P}$ ollinators are inextricably linked to human well-being through the maintenance of ecosystem health and function, wild plant reproduction, crop production and food security. Pollination, the transfer of pollen between the male and female parts of flowers that enables fertilization and reproduction, can be achieved by wind and water, but the majority of the global cultivated and wild plants depend on pollination by animals. Although most animal pollinators are insects (for example, bees, flies, butterflies, moths, wasps, beetles and thrips), some vertebrate pollinators exist (for example, birds, bats and other mammals and lizards). Bees are the most important group of pollinators, visiting more than $90 \%$ of the leading 107 global crop types ${ }^{1}$. Over 20,000 bee species have been described worldwide ${ }^{2}$, of which up to 50 species are managed, and about 12 are commonly used for crop pollination, such as the western honeybee (Apis mellifera), the eastern honeybee (Apis cerana), some bumblebees, stingless bees and solitary bees. Apis mellifera is the most commonly managed bee in the world, although there is growing evidence highlighting the roles of wild pollinators and of diverse pollinator assemblages in contributing to global crop production ${ }^{3}$.

Our knowledge and response actions have not kept pace with the threats to pollinators and pollination services. Although there has been increased interest from science ${ }^{4}$, policymakers ${ }^{5,6}$ and the public, a mismatch remains between scientific evidence of impacts and conservation, and management responses. As a step towards further outreach to a wider audience, here we review the diverse values of pollinators, their status and trends, risks from environmental pressures and consequent management and policy response options, and highlight key knowledge gaps. Our review is robustly underpinned by the Intergovernmental Science-Policy Platform on Biodiversity and Ecosystem Services Pollinators, Pollination and Food Production assessment ${ }^{5}$, whose 77 international experts critically evaluated the available global evidence up until May 2015; we have also drawn upon key publications arising after this date.

\section{Diversity of values of pollinators and pollination}

Pollinators provide numerous benefits to humans, such as securing a reliable and diverse seed and fruit supply, sustaining populations of wild plants that underpin biodiversity and ecosystem function, producing honey and other beekeeping products, and supporting cultural values. Much of the recent international focus on pollination services has been on the benefits to food production. Animal pollination directly affects the yield and/or quality of approximately $75 \%$ of globally important crop types, including most fruits, seeds and nuts and several high-value commodity crops such as coffee, cocoa and oilseed rape ${ }^{1,7}$. An estimated $5-8 \%$ of global crop production would be lost without pollination services, necessitating changes in human diets and a disproportionate expansion of agricultural land to fill this shortfall in crop production by volume ${ }^{8}$. Over the past 50 years, yields of crops with greater pollinator dependence have increased at a lower rate, and become more variable than crops that are less pollinatordependent, suggesting that pollination services can be compromised by pollinator decline ${ }^{9}$. However, these estimates are often based on broad categorizations of pollinator dependence ${ }^{1}$ derived from older, less standardized literature. A better understanding of the relationships between pollination services and crop productivity is therefore essential to quantify correctly how changing pollinator populations or diversity will affect food production.

Recent research indicates that pollinator-dependent crop productivity is important for balanced human diets. Pollinator-dependent crops are the principal sources of many micronutrients, including vitamins A and C, calcium, fluoride and folic acid ${ }^{10}$. Nutritional dependency on pollination overlaps geographically with the incidence of malnutrition of these nutrients. For example, areas with a high vitamin A deficiency are estimated to be three times more reliant on pollinator-dependent crops for plantbased vitamin $\mathrm{A}^{11}$. Pollinator losses could therefore result in a substantial rise in the global rate of preventable diseases, such as ischaemic heart disease, potentially resulting in around 1.4 million additional deaths per year and approximately 29 million lost years of healthy life ${ }^{10}$. Although

\footnotetext{
${ }^{1}$ Centre for Agri-Environmental Research, School of Agriculture, Policy and Development, University of Reading, Reading RG6 6AR, UK. ${ }^{2}$ Ecology Department, Biosciences Institute, S. Paulo University, 05508-090 S. Paulo Brazil and Vale Institute of Technology Sustainable Development, Belém 66055-090, Brazil. ${ }^{3}$ Intergovernmental Science-Policy Platform on Biodiversity and

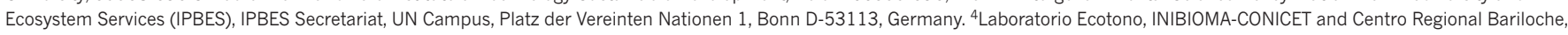

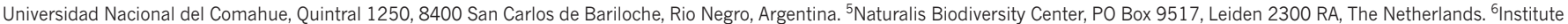

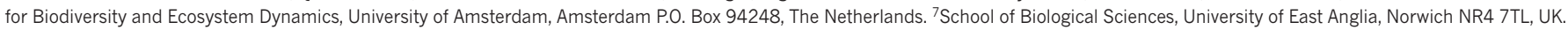

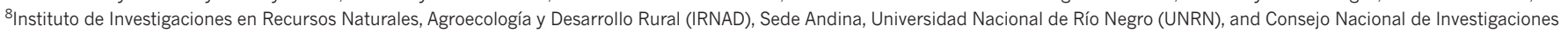
Científicas y Técnicas (CONICET), Mitre 630, CP 8400, San Carlos de Bariloche, Río Negro, Argentina. ${ }^{9}$ CSIRO Land and Water and James Cook University Division of Tropical Environments and

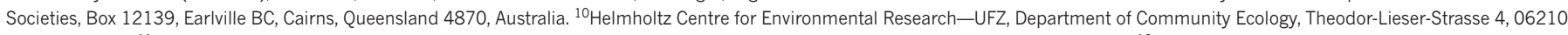
Halle, Germany. ${ }^{11} \mathrm{i}$ Div, German Centre for Integrative Biodiversity Research, Halle-Jena-Leipzig, Deutscher Platz $5 \mathrm{e}, 04103$ Leipzig, Germany. ${ }^{12} \mathrm{NERC}$ Centre for Ecology and Hydrology, Bush Estate, Penicuik, Edinburgh EH26 OQB, UK.
} 


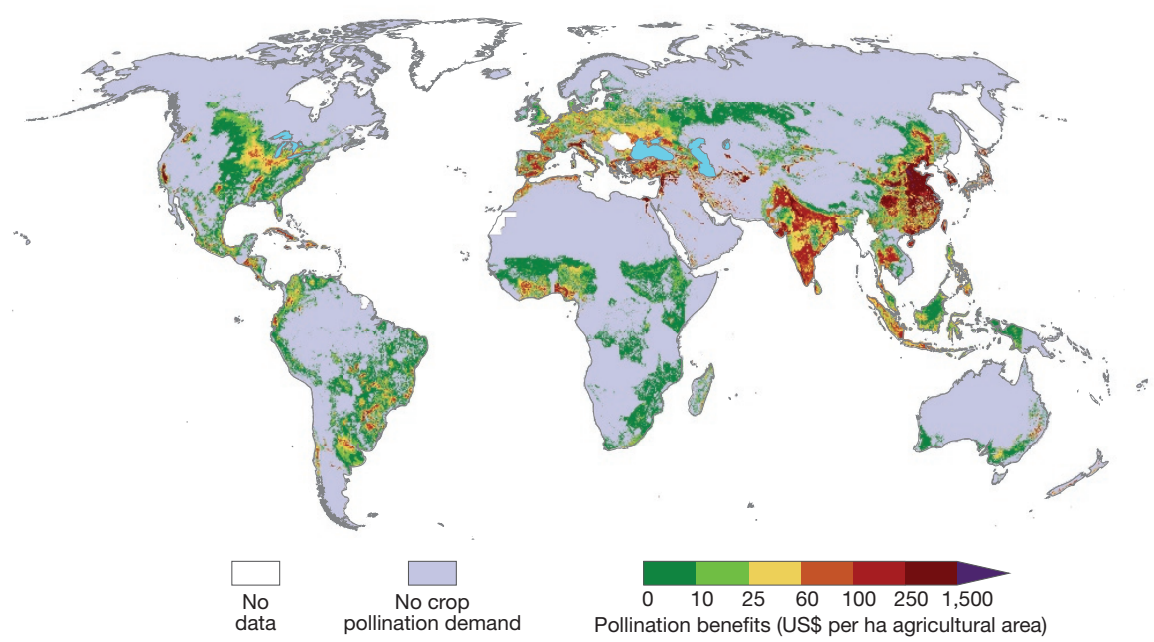

Figure 1 | Pollination service contribution to the crop market output in terms of US\$ per hectare of added production. Benefits are given for the year 2000 and have been corrected for inflation (to the year 2009) and for purchasing power parities. Plotted on a $5^{\circ}$ by $5^{\circ}$ latitude-longitude grid. Figure is adapted from ref. 4 .

these studies provide estimates of qualitative risks, accounting for the distribution of food throughout the world would result in a better understanding of the effect of pollinator declines on human diets and health.

Animal pollination substantially affects global crop markets, with animal-pollinated crops often having higher sale prices than pollinatorindependent crops. On the basis of 2009 market prices and production, animal pollination services enhance global crop output by an additional US\$235-577 billion (inflated to 2015 US\$) annually ${ }^{4}$. These economic benefits are unevenly distributed, with the greatest benefits in southern and eastern Asia and Mediterranean Europe, owing to greater production of highly pollinator-dependent crops and higher market prices (Fig. 1). The resultant price rises could reduce crop consumer welfare by an estimated US\$160-191 billion (inflated to 2015 US\$) and welfare in other, related markets such as agrochemicals, by a further US $\$ 472-546$ billion ${ }^{12}$ (inflated to 2015 US\$) owing to shifts in crop production patterns towards lower input crops and non-agricultural activity.

The estimated relative economic impacts of pollinator losses on local producer and consumer welfare are greatest in western, northern and central Africa ${ }^{12}$, highlighting a mismatch between total economic benefits and local effects on producers and consumers. Currently, economic analyses are limited by ecological and economic data gaps. Emerging methods, using holistic agro-ecological data, can redress this by directly linking marginal pollinator population shifts to crop output and welfare ${ }^{13}$, supporting more precise decision-making at local scales.

Many of the most widely grown and valuable cash crops, such as cocoa, almonds and coffee, are animal-pollinated ${ }^{1}$; they provide employment and income for millions. Agriculture employs 1.4 billion people, approximately one-third of the world's economically active labour force ${ }^{14}$. This is particularly important to the world's poorest rural communities, $70 \%$ of whom rely on agriculture as the main source of income and employment ${ }^{15}$. More than 2 billion people in developing nations ( $83 \%$ of the global agricultural population) are reliant on smallholder agriculture, an area that has been largely neglected in pollinator research ${ }^{16}$. A recent study across small and large farms from Africa, Asia and Latin America found that, in fields that are 2 hectares or less, yield gaps owing to pollination deficits could be closed by a median of $24 \%$ through higher pollinator density. In larger fields, such benefits only occurred at high pollinator species richness ${ }^{17}$. This highlights the positive links between pollinators and yields in small- and large-holding crop systems worldwide.

Beyond food provisioning, pollinator-dependent plants contribute directly to medicines, biofuels, fibres, construction materials, musical instruments, arts, crafts and recreation activities. A case study in India found that $40 \%$ of plants that provide non-timber forest products, including medicine and construction materials, benefit to some extent from pollination services ${ }^{18}$. The use of animal pollinated biofuel crops is growing, with the cultivation area of oilseed rape, sunflowers and soybeans increasing by 4.2 million hectares (32\%) across Europe between 2005 and 2010 (ref. 19).

Bees can help to ensure livelihood security and alleviate poverty among rural communities through honey-hunting and beekeeping practices based on indigenous and local knowledge, documented in more than 50 countries $^{20,21}$. These practices typically require minimal investment, generate diverse saleable products, can occur often without land ownership or rent, provide flexibility in timing and locations of activities, link to culture and traditions, and produce family nutrition and medicinal benefits ${ }^{22}$. Anti-bacterial, anti-fungal, and anti-diabetic agents can be derived from honey; a recent review has found evidence that honey, as a topical treatment, can heal burns more quickly than conventional dressings ${ }^{23}$.

Pollinators and their products also benefit society indirectly as sources of inspiration for art, music, literature, religion, traditions, technology and education. Bees inspire texts and imagery in many global religions, with examples including the Surat $\mathrm{An}-\mathrm{Na} \hat{h} \mathrm{l}$ in the Qur'an, the three-bee motif of Pope Urban VIII and sacred passages within Hinduism, Buddhism and Chinese traditions such as the Chuang Tzu. For many people, a good quality of life arises from the role of pollinators as symbols of identity, from aesthetically important flowers in landscapes ${ }^{24}$, in social relations, and globally significant heritage. Many sites listed under the Convention Concerning the Protection of the World Cultural and Natural Heritage depend on pollination to maintain their values, including the Classic Gardens of Suzhou in China and the Agave Landscape and Ancient Industrial Facilities of Mexico. The Convention for the Safeguarding of the Intangible Cultural Heritage recognizes several practices that rely on pollinator-dependent plants as internationally important, including the Argan practices and know-how concerning the argan tree (Argania spinosa) from Morocco, and Kimjang, making and sharing kimchi from the Republic of Korea.

At present, markets and economic indicators fail to capture all benefits from pollinators, and the full costs of supporting managed pollinators. As many land-use decisions rely on market forces and economic indicators, such failures can result in sub-optimal land management decisions that erode these benefits. Integrated monetary and non-monetary valuations of pollinator gains and losses can better inform decision-making on land-use, but will require the use of transdisciplinary methods, such as deliberative multi-criteria cost-benefit analysis that supports consideration of trade-offs among multiple dimensions.

\section{Status and trends of pollinators and pollination}

Information for assessing trends for wild pollinators comes from two main sources. First, historical information from museum collections and 
a Structure of the IUCN Red List categories
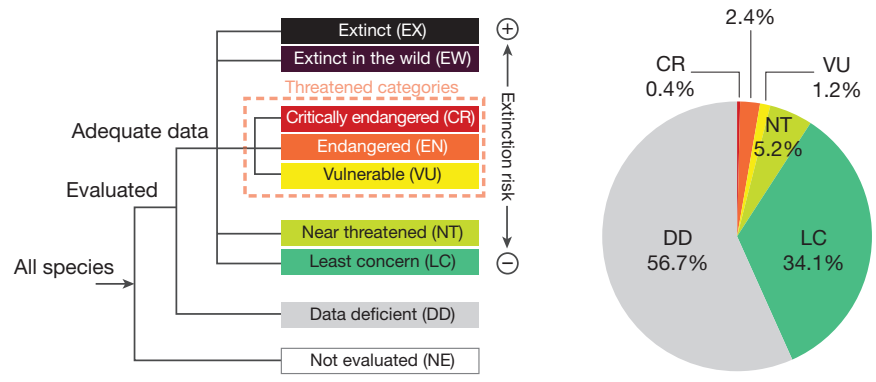

Bees

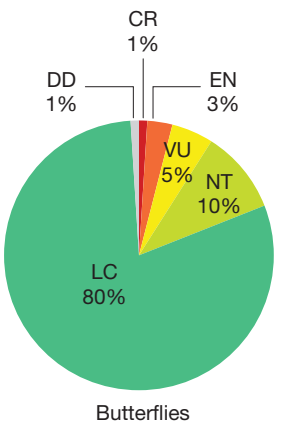

Butterflies

C IUCN Red List status of vertebrate pollinators across regions

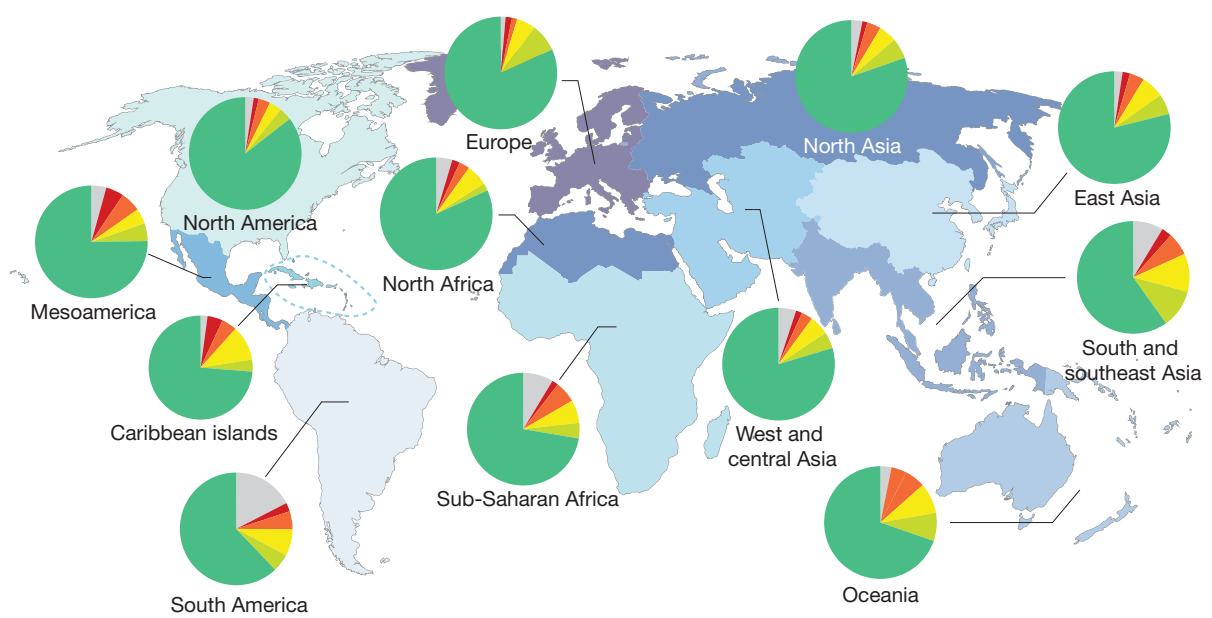

Figure 2 The International Union for Conservation of Nature (IUCN) Red List status of wild pollinator taxa. a, Standardised IUCN extinction risk categories. b, European bees and butterflies. c, Vertebrate pollinators (including mammals and birds) across IUCN regions. IUCN relative risk

records collected by amateur naturalists and scientists; second, recently initiated surveys responding to concerns about pollinator declines. Although data are available only for some pollinator groups and for a few global regions, evidence is clear that several species have reduced their geographical ranges, a handful have gone extinct, and many have shown declines in local abundance. Global International Union for Conservation of Nature (IUCN) Red List assessments for vertebrate pollinator species (mostly birds and bats) estimate that $16.5 \%$ are threatened with global extinction (increasing to $30 \%$ for island species), trending towards more extinctions $^{25}$ (Fig. 2). For insect pollinators, the most important group of pollinators in the majority of biomes, a regional Red List assessment is available only for Europe, which indicates that $9 \%$ of bees ${ }^{26}$ and $9 \%$ of butterflies ${ }^{27}$ are threatened (Fig. 2). The figure for bees may increase substantially when more species are evaluated because the lack of data currently precludes assessment of $57 \%$ of European species. National Red Lists for bees are available for several European countries and indicate that up to $50 \%$ of bee species are nationally threatened ${ }^{26}$.

Declines in bee diversity over the last century have been recorded in highly industrialized regions of the world, particularly northwestern Europe and eastern North America ${ }^{28-33}$. Several bumblebee species have severely declined in occurrence, for instance Franklin's bumblebee (Bombus franklini) in the western United States, Cullum's bumblebee (Bombus cullumanus) in Europe and the giant bumblebee of Patagonia (Bombus dahlbomii) $^{5}$. Declines in diversity in some areas, for example the Netherlands and the United Kingdom, seem to have slowed down in recent decades, but populations are still far below pre-decline levels of the early twentieth century ${ }^{32}$. Pollinators are also shifting ranges to more temperate latitudes or higher altitudes, following climate change, but often seem unable to track temperature shifts completely. Northern categories: EX, extinct; EW, extinct in the wild; CR, critically endangered; EN, endangered; VU, vulnerable; NT, near threatened; LC, least concern; DD, data deficient; NE, not evaluated. Figure adapted from ref. 5.

Hemisphere bumblebees, for example, are losing suitable habitat at their southern range limits but are not expanding consistently at their northern range limits ${ }^{34}$

The most widespread managed pollinator is the western honeybee (A. mellifera) and globally the number of hives has increased by $45 \%$ during the last five decades, despite a temporary drop during the 1990s after the dissolution of the Soviet Bloc $^{35}$. National trends vary widely among countries (Fig. 3); for example there were recent declines in the United States and Germany but large increases in China, Argentina and Spain during the same period. More recently, many countries around the world report large-scale seasonal losses ${ }^{36,37}$. National and local declines may not necessarily lead to more long-term colony losses as in some cases beekeepers can, at an economic cost, make up for seasonal colony loss by splitting colonies later in the season.

Shifts in wild and managed pollinator abundance, community diversity and composition may lead to shifts in flower visitation and ultimately affect fruit or seed set in wild plants and crops. The impact depends on the level of redundancy reflected in plant-pollinator interaction networks. Large and well-connected plant-pollinator networks are more likely to provide acceptable levels of pollination to plants as well as sufficient floral resource availability to pollinators. Networks show considerable changes in space and time, but whether and when networks suffer irreversible change following pollinator losses is not well understood (but see ref. 38).

Loss of both wild and managed pollinators may negatively affect human food production as many crop types rely, at least to some extent, on animal pollination for the quantity and/or quality of their yield ${ }^{1}$. The production of crops that depend directly on pollinators constitutes a small proportion of the global food volume (5-8\%). However, despite being small, the fraction of total agricultural production that depends directly on pollinators 

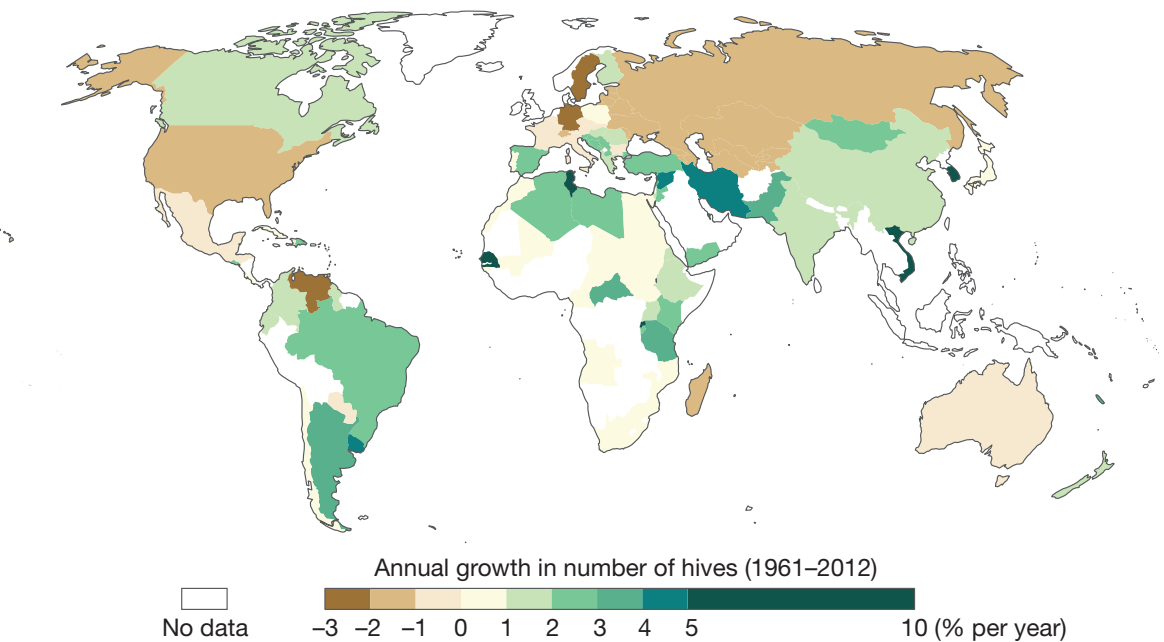

Figure 3 | Annual growth rate (percentage per year) in the number of honeybee hives for countries reporting data to the Food and Agriculture Organization (FAO) between 1961 and 2012. Data values are displayed at the country level; however, the distribution of honeybee hives is spatially heterogeneous within countries. Figure is based on data from the FAO (http://faostat.fao.org/, 2013).

has increased fourfold over the last five decades compared to a twofold increase in the fraction that does not depend on pollinators ${ }^{5,8}$ (Fig. 4). Consequently, global agriculture is now twice as dependent on pollinators compared to five decades ago. There are strong regional patterns in the pollinator-dependence of agriculture, with higher dependence in countries growing cash crops such as coffee, almonds, cocoa, soybeans or rapeseed at large scales ${ }^{4}$. Crops that depend on pollinators have experienced the fastest global expansion in cultivated area and account for most of the approximately $30 \%$ expansion of global agricultural land during these five decades ${ }^{39}$. Although yields show growth in most crops, owing to technological developments, pollinator-dependent crops have exhibited a slower average growth in yield, and higher inter-annual yield variability, than

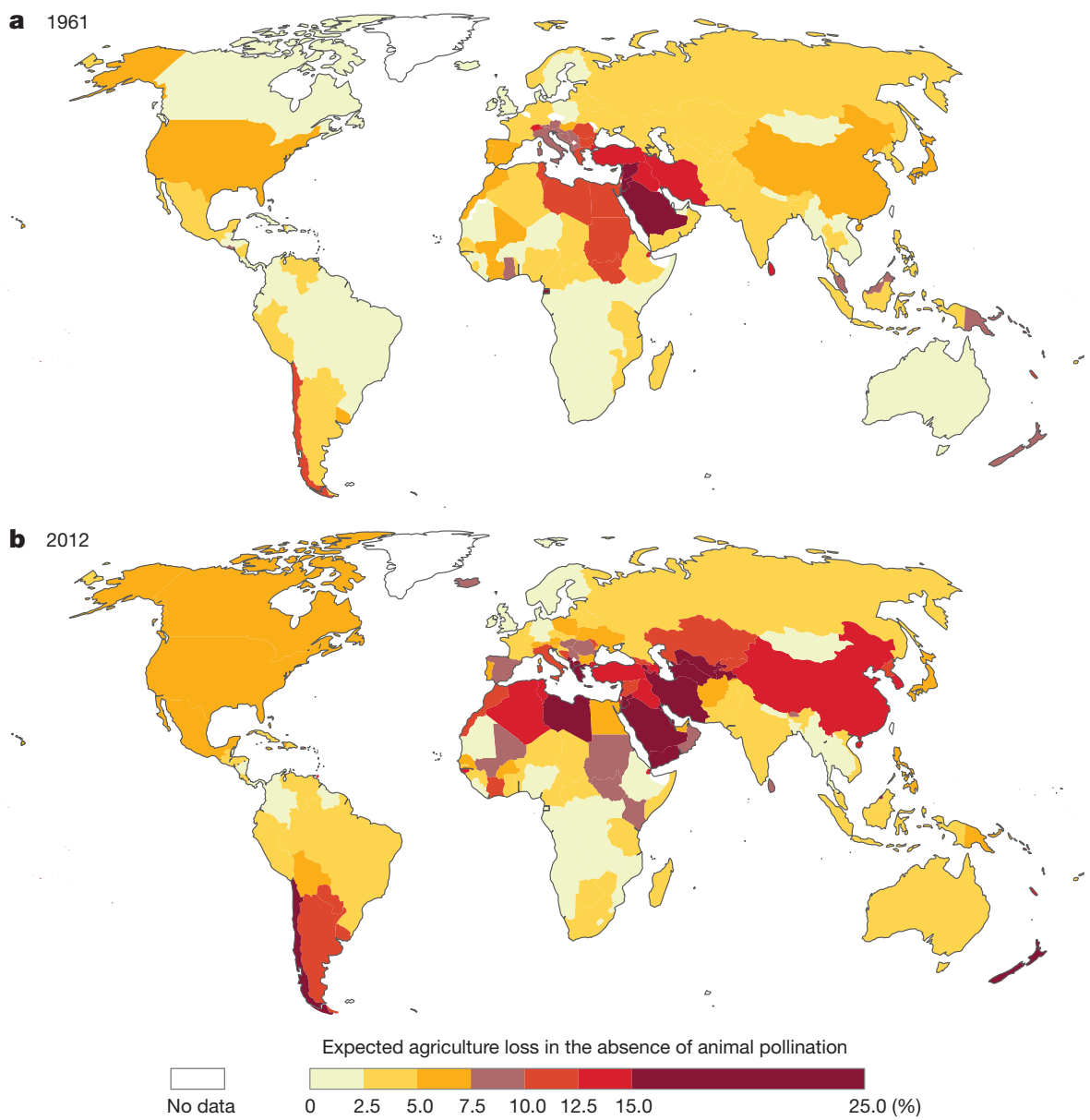

Figure 4 | Agriculture dependence on pollinators in 1961 and 2012. Figure is based on the FAO data set (http://faostat.fao.org/) and following the methodology of ref. 8. Data values are estimated at the country level; however the distribution of agricultural land, different crops and, thus, values of pollinator dependence are spatially heterogeneous within countries. 


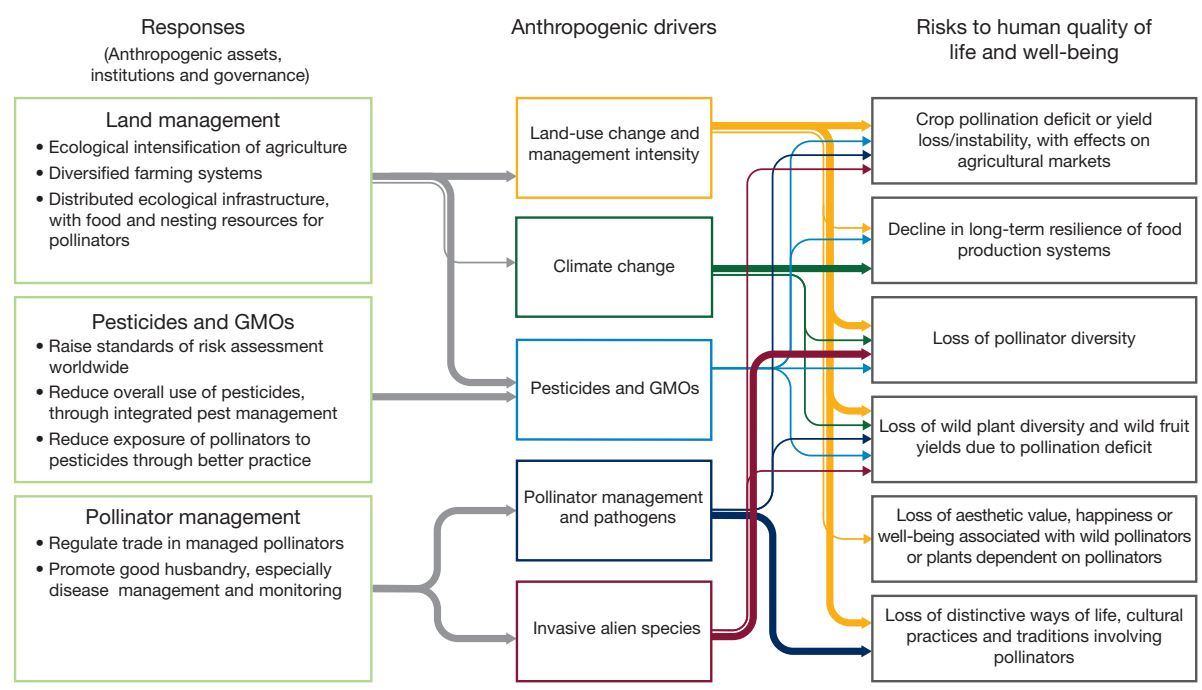

Figure 5 | Drivers, risks and responses to pollinator decline. Drivers of pollinator decline (central boxes) relate to the key risks associated with pollinator decline (right boxes), and how these drivers are addressed by three important sets of responses (left boxes) that ultimately reduce the risks. Responses combine elements of human facilities, knowledge, infrastructure and technology ('anthropogenic assets') with institutions and governance ${ }^{5}$. Arrows are thick if there is clear evidence that at least one of the responses can reduce the impact of the driver on pollinators,

pollinator-independent crops $^{9}$. At the field level, decreased crop yield is related to lower abundance and diversity of pollinators in many crops ${ }^{3,17}$. A higher density of flower visitors was the single most important factor improving yield in a study covering 33 pollinator-dependent crop systems across three continents ${ }^{17}$.

A loss of pollinators may have negative impacts on the reproduction of wild plants, as more than $90 \%$ of tropical flowering plant species and about $78 \%$ of temperate-zone species rely, at least in part, on animal pollination ${ }^{40}$. There is a lack of data on large-scale and long-term trends in pollination or seed production, although historical shifts in plant distributions have been documented. Wild plants in the Netherlands and United Kingdom that require bees for cross-pollination showed declines corresponding to those of the bees that pollinate them ${ }^{28}$. Similarly, declines are greatest for bee species that depend on forage plants that are also showing declines ${ }^{41}$. Although correlative, these patterns strongly suggest that plant and pollinator shifts are interdependent. Historical pollination rates can rarely be assessed, owing to the lack of quantitative data. However, analysis of pressed herbarium-specimens of pollinator-dependent orchids revealed that pollination had dropped from more than $40 \%$ to almost $0 \%$ in a century in Africa ${ }^{42}$. Further research is needed to understand the impacts of pollinator loss on wild plant communities and the other way around, particularly because a large part of wider biodiversity depends on the fruits, seeds and plant communities that pollinators maintain.

While shifts in pollinator diversity and ranges are relatively well-documented in parts of Europe and North America, a lack of wild pollinator data (species identity, distribution, occurrence and abundance) for Latin America, Africa and Asia limit any general conclusions on regional status and trends ${ }^{43}$. Only long-term international and national monitoring of both pollinators and pollination can provide information for the majority of species and most parts of the world.

\section{Drivers of change and responses}

Comprehensibly linking observed long-term pollinator declines ${ }^{29,30,32}$ with specific or multiple drivers is not often possible owing to the lack of data on the status of pollinators (but see refs 44,45 ). Nonetheless, a wealth of studies worldwide point to a high likelihood that several anthropogenic drivers are threatening the abundance, diversity and health of wild and managed pollinators, and the pollination services they provide to wild or clear evidence that the driver generates the impact underlying the risk, at least in some circumstances. Arrows are thin if the link between response and driver, or driver and risk, is suspected or inferred by current evidence, but direct empirical evidence of it taking place is either sparse or lacking. This list of responses to pollinator decline is not exhaustive. There are 74 responses listed in ref. 5. Many responses also represent opportunities to improve livelihoods and environments directly. GMOs, genetically modified organisms.

plants and crops ${ }^{46,47}$. Figure 5 shows the five major drivers of pollinator decline identified in the literature.

Some drivers generate many stressors for pollinators (for example, increased land management intensity leads to loss of habitat and reduced floral resource supply), whereas interactions between drivers (for example, land-use, pesticides and climate change) may increase overall impact ${ }^{46,47}$. The drivers create risks to human quality of life and well-being by eroding the benefits that humans obtain from pollinators and their pollination services (Fig. 5). From a scientific technical perspective, a risk is usually understood as the probability of a specific hazard or effect taking place, and risks are evaluated by estimating both the probability and the size or scale of the impact. Here we identify six risks to human well-being generated by pollinator decline. Given the substantial knowledge gaps regarding the status, trends and drivers of change in pollinators in most regions of the world, it is not yet possible to evaluate or rank these different risks quantitatively. Instead, we provide an overview of what is known about the link between each driver and risk (summarized in Fig. 5). For each major driver, we consider available responses and summarize what is known about their likely effectiveness (Fig. 5).

\section{Changes in land-use and management intensity}

Pollinators and pollination services are threatened by land-use changes involving the destruction, fragmentation and degradation of semi-natural habitats or the conversion of diversified farming systems into conventional intensive agriculture (that is, large, homogenous fields with high agrochemical inputs and intensive tillage, grazing or mowing) ${ }^{46,47}$. Such land-use changes and management intensification can reduce or modify the supply of floral (pollen and nectar) and nesting resources to pollinators ${ }^{28,41,48}$, often leading to lowered pollinator density or diversity and homogenized pollinator community structure ${ }^{45,49}$. Changes to pollinator floral resources in contemporary intensive landscapes ${ }^{48}$ could lead to malnutrition of individuals and colony stress, and increase vulnerability to pesticides and pathogens (see below) through impaired ability of the insect immune system to break down toxins in the $\operatorname{diet}^{47,50}$.

Mitigating the pollinator-associated risks to humans driven by land-use change (Fig. 5) requires strategies that reverse or slow landscape homogenization. Current management options that enhance pollinator diversity or foraging densities at local and, to a lesser degree, landscape scales ${ }^{51-53}$ 


\section{BOXI Three complementary approaches to safeguard pollinators in agro-ecosystems}

\author{
Ecological intensification ${ }^{61}$
}

This involves field and landscape management to increase the intensity of ecosystem services, such as biotic pest regulation, nutrient cycling and pollination, to enhance agricultural productivity and reduce reliance on agro-chemicals. Some specific actions to achieve ecological intensification are those that improve conditions for pollinators, such as creating flower-rich field margins ${ }^{56}$. However, under ecological intensification, these actions are designed to facilitate on-farm pollination of particular crops. Promoting ecological intensification via agricultural extension services to demonstrate applications and convey the economic value of pollination services would probably increase adoption of beneficial practices ${ }^{80}$. However, there are gaps in scientific understanding of the extent to which ecological intensification can assure farm yields (but see ref. 17), increase profitability at the farm scale, or which practices are the most effective to achieve these outcomes.

\section{Strengthening diversified farming systems}

Measures (tailored to the particular landscape) such as intercropping, using crop rotations that include flowering crops, agroforestry, managing forest or home gardens, and creating, restoring or maintaining native wild flower habitats, can be expected to foster diverse pollinator communities and pollination ${ }^{111,112}$. Existing diversified farming systems are supported by many indigenous peoples and local communities worldwide, based on their cultural practices and knowledge systems. For example, central American milpa systems contain diverse plant communities attractive to insects ${ }^{65}$ and home gardens in Mexico increase the fruit set of the columnar cactus Stenocereus stellatus ${ }^{113}$. Shifting cultivation systems under some circumstances support a diversity and abundance of floral resources for pollinators, through practices including integrating crops with flowering trees, customary rules that protect pollinator habitat ${ }^{114}$ and incorporation of wild plants in the production system ${ }^{115}$.

\section{Ecological infrastructure}

This infrastructure, needed to benefit crop pollination services, comprises small- to medium-sized patches of natural or semi-natural habitat ( $<10 \mathrm{ha}$ ), distributed throughout agricultural landscapes providing nesting and floral resources within reach of foraging pollinators (typically $500 \mathrm{~m}$ to $1 \mathrm{~km}$ between patches). The same approach should benefit pollinators and crop pollination in urban areas, although both agricultural and urban landscapes providing larger patches of natural habitat will probably increase regional pollinator diversity 116,117 . Road verges, power lines, railway banks and waterways within and between urban areas have a large potential to become valuable infrastructure for supporting pollinators, if managed appropriately to provide flowering and nesting resources ${ }^{118}$. Connecting pollinator habitat patches together with such linear features enables movement of pollinators and can also enhance pollination of wild plants ${ }^{19,120}$, although its role in maintaining pollinator populations remains unclear.

include organic farming practices ${ }^{49,54,55}$ and planting flower strips that provide floral resources ${ }^{56}$. The efficacy of these measures, however, tends to be greatest in landscapes dominated by intensive agriculture, offering few floral resources ${ }^{54,56}$. We argue that achieving sustainable, productive agriculture commensurate with pollinator and wider biodiversity on a large scale will require three complementary approaches, namely: (i) ecological intensification; (ii) strengthening diversified farming systems; and (iii) investing in ecological infrastructure by creating patches of (semi-)natural habitat throughout landscapes (Box 1).

There are potential trade-offs between maximising crop yield through conventional means and improving conditions for pollinator biodiversity with enhanced delivery of pollination services ${ }^{57}$. For example, many farming systems using current organic practices usually produce lower crop yields ${ }^{58}$, although some studies have demonstrated that yields of insect-pollinated crops can be improved through enhanced pollination services under organic management ${ }^{59,60}$. Similarly, providing ecological infrastructure, such as flower strips or other habitat, may risk overall yield reductions by taking farmland out of direct crop production. To date, however, the only study to test this found that over several years the yield lost at the farm scale was balanced by a yield gain in pollinator-dependent crops grown in rotation 61 .

Most of the scientific evidence on the efficacy of organic farming and growing flower strips in aiding pollinator biodiversity and pollination services is from Europe and North America ${ }^{55,56}$, so caution is needed in extrapolating to other regions that differ in farm practices, underlying biodiversity and landscape character. Nonetheless, across the world managing the farm or landscape for wild pollinators coupled with use of managed bees results in the highest yields for animal-pollinated crops ${ }^{3}$. These improvements in pollination are partly due to higher local pollinator densities and partly due to higher pollinator species diversity providing complementarity or redundancy in service provision ${ }^{3,17}$.

The policies and practices involved in ecological intensification, strengthening diversified farming systems and maintaining or providing ecological infrastructure can also have wider livelihood benefits for rural communities. These benefits can be fostered through holistic responses including food sovereignty ${ }^{62}$, and biocultural conservation approaches ${ }^{63}$ that recognize rights, support economies and address negative multipliers of land-use change effects such as loss of access to traditional territories and loss of traditional knowledge ${ }^{64}$. Many of the 32 Globally Important Agricultural Heritage Systems are based on indigenous and local knowledge that support the roles of pollinators in maintaining plant diversity, such as for lemons in the pergola-growing lemon gardens of southern Italy. Indigenous peoples and local communities view some of their practices as supporting an abundance and diversity of pollinators, for example favouring heterogeneity in landscapes and gardens, fostering pollinator resources, and recognizing kinship relationships that require respect and care for pollinators ${ }^{65}$.

\section{Pesticides}

The risk to pollinators from pesticides (including insecticides, acaricides, fungicides, molluscicides and herbicides) is through a combination of toxicity and level of exposure. This risk varies according to the species' biology (for example, ability to metabolize toxins, foraging ecology), between chemical compounds, with the type and scale of land management ${ }^{66,67}$, interactions with other stressors ${ }^{47,50}$, and with landscape ecological infrastructure ${ }^{68}$. Herbicides, used to control weeds, pose an indirect risk because they reduce the abundance and diversity of flowering plants providing pollen and nectar to pollinators ${ }^{69}$.

Under controlled experimental conditions, pesticides, particularly insecticides like neonicotinoids, have a broad range of lethal and sublethal (for example, behavioural and physiological) effects on pollinators ${ }^{66,67,70,71}$ and, dependent on the concentration pollinators are exposed to, may reduce the pollination service that they provide ${ }^{72}$. The few available true field studies assessing the effects of field-realistic exposure on pollinators provide conflicting evidence of their effect based on the species studied and pesticide used ${ }^{66}$. For example, a recent landscape-scale field experiment showed reduced wild pollinator survival and reproduction following actual field exposure to a neonicotinoid ${ }^{73}$. However, evidence for negative effects on managed honeybees at the colony scale is often conflicting or its biological significance is contested $66,67,70,71,73$.

Substantial gaps in knowledge remain regarding the effects of pesticides on pollinators. What constitutes actual field exposure is complicated by the ecology and foraging behaviours of different insect species in different land-use contexts ${ }^{66,67,71}$. It is unclear whether sublethal effects on individual insects scale up to colonies and populations of managed bees and wild pollinators, especially over the longer-term ${ }^{66,70,71}$. The potentially synergistic and long-term impacts of pesticide mixtures on insect individuals, colonies, and populations remain largely unresolved ${ }^{47,67,70,74}$, although there is some correlational evidence linking reduced wild bee population persistence to neonicotinoid treatment of oilseed rape crops in England ${ }^{75}$. Moreover, studies of sublethal insecticide effects have mainly tested a limited range of pesticides on a few bee species ${ }^{66,67,70,71}$.

Despite the uncertainties, we can lower risks of pesticides to pollinators (and other non-target organisms) by decreasing levels of non-target toxicity and reducing exposure. Rigorous risk assessment of specific 
pesticide ingredients and subsequent regulation have been shown to lower the overall environmental hazard from pesticides at a national scale $\mathrm{e}^{76,77}$. Regulatory risk assessments are usually only conducted on the western honeybee $A$. mellifera, which is not always a reliable surrogate for other pollinators, so broadening the set of species tested is one way of improving risk estimates ${ }^{47}$. Pesticide exposure can be reduced by decreasing the usage of pesticides, for example, by adopting integrated pest management practices that only apply pesticide when pest pressure reaches an economic threshold ${ }^{78}$. The effects of pesticides can be lessened through application practices, including the use of technologies to reduce pesticide spray $\mathrm{drift}^{79}$ or decreasing herbicide use and adopting less stringent approaches to weed control, thereby allowing a variety of flowering weeds to flourish and support more diverse pollinator communities ${ }^{54}$.

Education and training of farmers and the public are necessary to ensure the safe use of pesticides in agricultural and urban settings. Policy strategies that can help to reduce pesticide use, or avoid misuse, include supporting farmer field schools, known to increase the adoption of integrated pest management practices ${ }^{80}$, and adopting national targets, codes of conduct or plans for risk reduction ${ }^{81,82}$.

Research is needed (potentially co-developed with agri-business or farming communities) to provide viable alternatives to conventional highchemical-input systems. The efficacy of pest management in pesticide-free and pesticide-minimized (for example, by integrated pest management) farming systems needs to be improved and the role of ecological intensification and/or ecological infrastructure (Box 1) in sustaining beneficial biodiversity while assuring farm profitability and yields needs to be studied. In all cases, protection of pollinators through reduced use or removal of very toxic chemicals from markets should be balanced against the need to ensure agricultural yields and food security.

\section{Genetically modified crops}

Most agricultural genetically modified organisms carry traits for herbicide tolerance or insect resistance. Although lethal risks from genetically modified crops to most pollinators are low, there are indirect risks from the management of these crops that need further evaluation. No lethal effects of insect-resistant crops from direct toxicity of pollen and nectar have been reported for bee species, although some have been observed in flower-visiting insects, such as beetles, butterflies and moths, that are closely related to the target pests ${ }^{83}$. Management of herbicide-tolerant crops by eliminating weeds is likely to diminish floral resources for pollinators, although this remains little-studied ${ }^{84}$. In one case, lower bee abundance in herbicide-tolerant fields led to an oilseed rape pollination deficit ${ }^{59}$. Insect-resistant crops (for example, producing Bacillus thuringiensis toxins) can reduce insecticide use, although this varies with the crop and the prevalence of target and non-target pests in different regions. Reduced pesticide use accompanying insect-resistant crops could lower this pressure on non-target insects ${ }^{85}$, but how it affects pollinators specifically is unknown. Moreover, the emergence of secondary outbreaks of non-target pests or primary pest resistance can lead to a resumption of pesticide use $\mathrm{s}^{86,87}$. The potential effects on pollinators of transgene flow and introgression (that is, gene substitution) in wild plant relatives and non-genetically modified crops require further study.

Environmental risk assessment is required for the commercial release of genetically modified crops in countries that are signatories of the Cartagena Protocol on Biosafety (Convention on Biological Diversity; https://bch.cbd.int/protocol). As for pesticides this regulatory framework uses a single pollinator species in toxicological assessment-the western honeybee A. mellifera. In addition, it does not address the sublethal or indirect effects of herbicide-tolerant and insect-resistant crops on pollinators ${ }^{88}$. Further research would help inform the extent that policy responses are required in this area.

\section{Pollinator management and pathogens}

Insect pollinators suffer from a broad array of fungal, bacterial and viral pathogens and protozoan and invertebrate parasites ${ }^{46,47}$. Host shifts mean that they represent a substantial current and future threat to the health of bees, as seen with Varroa mites attacking and transmitting viruses among honeybees ${ }^{89}$. The risk of disease and rates of pathogen and parasite transmission to new pollinator hosts has been exacerbated by the commercial management, mass breeding, and transport and trade in pollinators beyond their original ranges, which has increased the incidence of biological invasions ${ }^{89-91}$. A notable example is the worldwide translocation of the western honeybee (A. mellifera) for its hive products and crop pollination services ${ }^{90}$. This has resulted in a spill-over of pests and pathogens, both within A. mellifera-in the case of the Varroa mite originally picked up from $A$. cerana-and possibly between species, from A. mellifera to wild pollinators, such as the deformed-wing virus ${ }^{89,92}$, although some pathogens may simply be shared generalists across flower visitors ${ }^{93}$. It has also caused a decline in the cultural practices associated with keeping other bees native to particular areas, for example, stingless bees in central America ${ }^{94}$. Commercial rearing of bumblebee species for crop pollination and their introduction to other continents has similarly resulted in biological invasions, pathogen transmission to native species and a decline of closely related congeners ${ }^{91}$.

Better regulation of national and international trade in managed pollinators species (and hive products), can help to limit the spread of parasites and pathogens and reduce the likelihood of ecological harm from further alien pollinator translocations. For instance, movement restrictions and biosecurity have so far prevented the establishment of Varroa mite into Australian populations of A. mellifera ${ }^{95}$.

Although the epidemiology of pollinator communities needs to be studied, promoting good husbandry of managed bees will probably reduce pathogen spread across managed and wild bee populations ${ }^{92}$. Other options to minimize disease effects may include selective breeding for genetic diversity and resistance traits, whereas RNA interference technology may help treat Varroa and virus infestations ${ }^{96}$.

\section{Invasive alien species}

The ecological effects of invasive alien species on pollinators and pollination are complex, but can be substantial under certain ecological and biogeographical circumstances. Invasive alien predators can transform ecosystems by consuming native pollinators, eliciting a shift to an invasivedominated pollination system. For example, in Hawaii (United States) and the Ogasawara archipelago (Japan), the alien wasp (Vespula pensylvanica) and lizard (Anolis carolinensis) predators, respectively, drove native bees to extinction, leaving pollination reliant on alien honeybees ${ }^{97,98}$. Alien plant or alien pollinator species modify native plant-pollinator networks, although the level of impact depends on the overlap in traits or niches, and at high abundances invasive alien pollinators can outcompete native pollinators ${ }^{91,98}$. A noteworthy example is the decline and local extinction of the Patagonian giant bumblebee (Bombus dahlbomii) from much of its range following the introduction of the managed European bumblebee species (B. terrestris and B. ruderatus $)^{99}$, and related loss of raspberry production due to style damage from excessive flower visitation by $B$. terrestris ${ }^{100}$. Invasive alien herbivores may indirectly disrupt pollination ${ }^{98}$, and another potential risk to native plants comes from exotic plant pathogens, perhaps introduced with alien plants and spread by insects.

Eradication of established invasive aliens is seldom successful beyond oceanic islands, and often prohibitively expensive. Consequently, the most effective policy responses are surveillance and regulation to prevent new invasions, and rapid management once detected to avoid establishment.

\section{Climate change}

The effects of climate change on pollinators and pollination services may not be fully apparent for several decades ${ }^{101}$. However, over recent decades, the seasonal activity, abundance and range of some wild pollinator species (for example, bumblebees and butterflies) have been correlated with observed climate change ${ }^{102,103}$. Most bumblebee distributions in Europe and North America are failing to track climate warming at the northern range limits of the species, leading to range contractions ${ }^{34}$. 
After 2050, all climate change scenarios reported by the Intergovernmental Panel on Climate Change suggest that the seasonal activity and ranges of many species may change differentially, disrupting life cycles and interactions between species and thus community composition ${ }^{104}$ The rate of change of the climate across the landscape is expected to exceed the maximum speed at which many pollinator groups are able to colonize new areas ${ }^{34,101}$. For some crops (such as apple and passion fruit) model projections at national scales have shown that these changes may disrupt crop pollination because of a future lack of overlap in the areas with the best climatic conditions for crops and their pollinators ${ }^{105-107}$. Habitat loss and fragmentation may worsen this by limiting compensatory species migration ${ }^{108}$, especially for species that are poor dispersers or habitat specialists $^{28,44,109}$. This may lead to increasingly species-poor plantpollinator communities dominated by highly mobile habitat-generalist species $^{44}$

Strategies to mitigate adverse effects of land-use change (Box 1 and Fig. 5), such as increasing crop diversity, regional farm diversity, and creating ecological infrastructure through targeted habitat conservation, creation or restoration, can help to secure pollinator diversity and pollination services for agriculture under climate change. Other measures, such as assisted translocation of pollinators to areas where pollination deficits arise, are untested and their effectiveness will probably be contextdependent ${ }^{110}$ and could pose threats to native pollinators.

\section{Outlook}

The potential risks to human well-being from pollinator decline mean that future research needs to understand which drivers and driver interactions are the most important in different contexts, to enable responses to be targeted. We encourage coordinated collaborative action and knowledge sharing to strengthen the establishment and implementation of the effective policy and management responses identified here to safeguard pollinators and pollination services for the long term.

\section{Received 15 April; accepted 1 November 2016.}

Published online 28 November 2016.

1. Klein, A. M. et al. Importance of pollinators in changing landscapes for world crops. Proc. R. Soc. B 274, 303-313 (2007).

2. Discover Life's Bee Species Guide and World Checklist; http://www.discoverlife. $\mathrm{org} / \mathrm{mp} / 20 \mathrm{q}$ ?guide=Apoidea_species\&flags=HAS (Ascher and Pickering 2014)

3. Garibaldi, L. A. et al. Wild pollinators enhance fruit set of crops regardless of honey bee abundance. Science 339, 1608-1611 (2013).

This study is the first to show consistent benefits from wild insects to crop pollination across the globe and that those benefits cannot be replaced by increasing the abundance of a single managed species such as honeybees.

4. Lautenbach, S., Seppelt, R., Liebscher, J. \& Dormann, C. F. Spatial and temporal trends of global pollination benefit. PLoS One 7, e35954 (2012).

This study is the most comprehensive and spatially explicit assessment of the direct economic benefits of pollination to global agriculture and accounts for differences in the effective spending power of different countries.

5. Potts, S. G. et al. IPBES. The Assessment Report of the Intergovernmental Science-Policy Platform on Biodiversity and Ecosystem Services on Pollinators, Pollination and Food Production; http://www.ipbes.net/node/44781 (2016).

6. Convention on Biological Diversity (CBD). UNEP Decisions Adopted by the Conference of the Parties to the Convention on Biological Diversity at its Fifth Meeting (UNEP/CBD/COP/5/23/Annex III). Decision V/5; https://www.cbd.int/ doc/decisions/COP-05-dec-en.pdf (Nairobi, 2000).

7. Gallai, N., Salles, J. M., Settele, J. \& Vaissière, B. E. Economic valuation of the vulnerability of world agriculture confronted with pollinator decline. Ecol. Econ 68, 810-821 (2009)

8. Aizen, M. A., Garibaldi, L. A., Cunningham, S. A. \& Klein, A. M. How much does agriculture depend on pollinators? Lessons from long-term trends in crop production. Ann. Bot. 103, 1579-1588 (2009).

This study is the first to take into account the partial dependence of most crops on pollinators in quantifying the effect of total loss of pollinators on global agricultural production, cultivated area and crop production diversity.

9. Garibaldi, L. A., Aizen, M. A., Klein, A. M., Cunningham, S. A. \& Harder, L. D. Global growth and stability of agricultural yield decrease with pollinator dependence. Proc. Natl Acad. Sci. USA 108, 5909-5914 (2011)

10. Smith, M. R., Singh, G. M., Mozaffarian, D. \& Myers, S. S. Effects of decreases of animal pollinators on human nutrition and global health: a modelling analysis. Lancet 386, 1964-1972 (2015).
11. Chaplin-Kramer, R. et al. Global malnutrition overlaps with pollinatordependent micronutrient production. Proc. R. Soc. B 281, 20141799 (2014)

12. Bauer, D. M. \& Wing, I. S. The macroeconomic cost of catastrophic pollinator declines. Ecol. Econ. 126, 1-13 (2016).

This study represents the most complete assessment of the consumer welfare impacts of pollinator losses both within and beyond crop markets.

13. Hanley, N., Breeze, T. D., Ellis, C. \& Goulson, D. Measuring the economic value of pollination services: principles, evidence and knowledge gaps. Ecosyst. Serv. 14, 124-132 (2015)

14. Altieri, M. A. Agroecology: the science of natural resource management for poor farmers in marginal environments. Agric. Ecosyst. Environ. 93, 1-24 (2002).

15. The World Bank. Agriculture and rural development; http://data.worldbank.org/ topic/agriculture-and-rural-development (2015)

16. Steward, P. R. et al. Pollination and biological control research: are we neglecting two billion smallholders. Agric. Food Security 3, 5 (2014).

17. Garibaldi, L. A. et al. Mutually beneficial pollinator diversity and crop yield outcomes in small and large farms. Science 351, 388-391 (2016).

18. Rehel, S. A. et al. Benefits of biotic pollination for non-timber forest products and cultivated plants. Conserv. Soc. 7, 213-219 (2009).

19. Breeze, T. D. et al. Agricultural policies exacerbate honeybee pollination service supply-demand mismatches across Europe. PLoS One 9, e82996 (2014).

20. Gupta, R. K., Reybroeck, W., van Veen, J. W. \& Gupta, A. Beekeeping for Poverty Alleviation and Livelihood Security. Vol. 1: Technological Aspects of Beekeeping (Springer, 2014).

21. Crane, E. The World History of Beekeeping and Honey Hunting (Routledge, 1999).

22. Hilmi, M., Bradbear, N. \& Mejia, D. Beekeeping and sustainable livelihoods. Food and Agriculture Organisation of the United Nations. Rural Infrastructure and Agro-Industries Division, Rome, Italy. (2011).

23. Jull, A. B. et al. Honey as a topical treatment for wounds. Cochrane Database Syst. Rev. 3, CD005083 (2015)

24. Junge, X., Schüpbach, B., Walter, T., Schmid, B. \& Lindemann-Matthies, P. Aesthetic quality of agricultural landscape elements in different seasonal stages in Switzerland. Landsc. Urban Plan. 133, 67-77 (2015).

25. Aslan, C. E., Zavaleta, E. S., Tershy, B. \& Croll, D. Mutualism disruption threatens global plant biodiversity: a systematic review. PLoS One 8, e66993 (2013)

26. Nieto, A. et al. European Red List of Bees (Luxembourg: Publication Office of the European Union, Belgium, 2014)

27. van Swaay, C. et al. European Red List of Butterflies (Luxembourg: Publication Office of the European Union, Spain, 2010).

28. Biesmeijer, J. C. et al. Parallel declines in pollinators and insect-pollinated plants in Britain and the Netherlands. Science 313, 351-354 (2006).

29. Cameron, S. A. et al. Patterns of widespread decline in North American bumble bees. Proc. Natl Acad. Sci. USA 108, 662-667 (2011).

30. Bommarco, R., Lundin, O., Smith, H. G. \& Rundlö, M. Drastic historic shifts in bumble-bee community composition in Sweden. Proc. R. Soc. B 279, 309-315 (2012)

31. Bartomeus, I. et al. Historical changes in northeastern US bee pollinators related to shared ecological traits. Proc. Natl Acad. Sci. USA 110, 4656-4660 (2013).

32. Carvalheiro, L. G. et al. Species richness declines and biotic homogenisation have slowed down for NW-European pollinators and plants. Ecol. Lett. 16, 870-878 (2013)

This study uses 32 million data points to assess shifts in diversity of pollinator groups and plants in the Netherlands, the United Kingdom and Belgium over the last 80 years.

33. Koh, I. et al. Modeling the status, trends, and impacts of wild bee abundance in the United States. Proc. Natl Acad. Sci. USA 113, 140-145 (2016).

34. Kerr, J. T. et al. Climate change impacts on bumblebees converge across continents. Science 349, 177-180 (2015).

35. Aizen, M. A. \& Harder, L. D. The global stock of domesticated honey bees is growing slower than agricultural demand for pollination. Curr. Biol. 19, 915-918 (2009).

36. Neumann, P. \& Carreck, N. L. Honey bee colony losses. J. Apic. Res. 49, 1-6 (2010).

37. Potts, S. G. et al. Declines of managed honeybees and beekeepers in Europe. J. Apic. Res. 49, 15-22 (2010)

38. Lever, J. J., van Nes, E. H., Scheffer, M. \& Bascompte, J. The sudden collapse of pollinator communities. Ecol. Lett. 17, 350-359 (2014).

39. Aizen, M. A., Garibaldi, L. A., Cunningham, S. A. \& Klein, A. M. Long-term global trends in crop yield and production reveal no current pollination shortage but increasing pollinator dependency. Curr. Biol. 18, 1572-1575 (2008)

40. Ollerton, J., Winfree, R. \& Tarrant, T. How many flowering plants are pollinated by animals? Oikos 120, 321-326 (2011)

41. Scheper, J. et al. Museum specimens reveal loss of pollen host plants as key factor driving wild bee decline in the Netherlands. Proc. Natl Acad. Sci. USA $111,17552-17557$ (2014).

42. Pauw, A. \& Hawkins, J. A. Reconstruction of historical pollination rates reveals linked declines of pollinators and plants. Oikos 120, 344-349 (2011).

43. Gill, R. J. et al. Protecting an ecosystem service: approaches to understanding and mitigating threats to wild insect pollinators. Adv. Ecol. Res 54, 135-206 (2016).

44. Burkle, L. A., Marlin, J. C. \& Knight, T. M. Plant-pollinator interactions over 120 years: loss of species, co-occurrence, and function. Science 339, 1611-1615 (2013). 
45. Senapathi, D. et al. The impact of over 80 years of land cover changes on bee and wasp pollinator communities in England. Proc. R. Soc. B 282, 20150294 (2015).

46. Potts, S. G. et al. Global pollinator declines: trends, impacts and drivers. Trends Ecol. Evol. 25, 345-353 (2010).

47. Vanbergen, A. J. \& the Insect Pollinators Initiative. Threats to an ecosystem service: pressures on pollinators. Front. Ecol. Environ 11, 251-259 (2013).

48. Baude, M. et al. Historical nectar assessment reveals the fall and rise of floral resources in Britain. Nature 530, 85-88 (2016).

49. Kennedy, C. M. et al. A global quantitative synthesis of local and landscape effects on wild bee pollinators in agroecosystems. Ecol. Lett. 16, 584-599 (2013).

This study is based on detailed spatial modelling of data from 39 crop systems globally to understand the relative influence of landscape composition, landscape configuration, farm management and their interactions on wild bee abundance and richness.

50. Collison, E., Hird, H., Cresswell, J. \& Tyler, C. Interactive effects of pesticide exposure and pathogen infection on bee health - a critical analysis. Biol. Rev. Camb. Philos. Soc. 91, 1006-1019 (2016).

51. Schneider, M. K. et al. Gains to species diversity in organically farmed fields are not propagated at the farm level. Nat. Commun. 5, 4151 (2014).

52. Carvell, C., Bourke, A. F. G., Osborne, J. L. \& Heard, M. S. Effects of an agri-environment scheme on bumblebee reproduction at local and landscape scales. Basic Appl. Ecol. 16, 519-530 (2015).

53. Jönsson, A. M. et al. Sown flower strips in southern Sweden increase abundances of wild bees and hoverflies in the wider landscape. Biol. Conserv. 184, 51-58 (2015).

54. Holzschuh, A., Steffan-Dewenter, I., Kleijn, D. \& Tscharntke, T. Diversity of flower-visiting bees in cereal fields: effects of farming system, landscape composition and regional context. J. Appl. Ecol. 44, 41-49 (2007).

55. Tuck, S. L. et al. Land-use intensity and the effects of organic farming on biodiversity: a hierarchical meta-analysis. J. Appl. Ecol. 51, 746-755 (2014).

56. Scheper, J. et al. Environmental factors driving the effectiveness of European agri-environmental measures in mitigating pollinator loss-a meta-analysis. Ecol. Lett. 16, 912-920 (2013).

This is the first study to provide an overview of the effectiveness of a range of agri-environment options for supporting local pollinator richness and abundance.

57. Blaauw, B. R. \& Isaacs, R. Flower plantings increase wild bee abundance and the pollination services provided to a pollination-dependent crop. J. Appl. Ecol. $\mathbf{5 1 , 8 9 0 - 8 9 8 ( 2 0 1 4 )}$

58. Ponisio, L. C. et al. Diversification practices reduce organic to conventional yield gap. Proc. R. Soc. B 282, 20141396 (2015).

59. Morandin, L. A. \& Winston, M. L. Wild bee abundance and seed production in conventional, organic, and genetically modified canola. Ecol. Appl. 15, 871-881 (2005)

60. Andersson, G. K. S., Rundlöf, M. \& Smith, H. G. Organic farming improves pollination success in strawberries. PLoS One 7, e31599 (2012).

61. Pywell, R. F. et al. Wildlife-friendly farming increases crop yield: evidence for ecological intensification. Proc. R. Soc. B 282, 20151740 (2015).

The first to test farm-scale 'ecological intensification', this study found no decrease in the crop yield over a five year rotation cycle on a large English farm, despite taking up to $8 \%$ of land out of production to support ecological functions.

62. van der Ploeg, J. D. Peasant-driven agricultural growth and food sovereignty. J. Peasant Stud. 41, 999-1030 (2014).

63. Gavin, M. C. et al. Defining biocultural approaches to conservation. Trends Ecol. Evol. 30, 140-145 (2015)

64. Gómez-Baggethun, E. \& Reyes-García, V. Reinterpreting change in traditional ecological knowledge. Hum. Ecol. 41, 643-647 (2013).

65. Lyver, P., Perez, E., Carneiro da Cunha, M. \& Roué, M. Indigenous and Local Knowledge about Pollination and Pollinators Associated with Food Production: Outcomes from the Global Dialogue Workshop http://unesdoc.unesco.org/ images/0023/002338/233811e.pdf ((Panama 1-5 December 2014) UNESCO: Paris, 2015)

66. Godfray, H. C. J. et al. A restatement of the natural science evidence base concerning neonicotinoid insecticides and insect pollinators. Proc. R. Soc. $B$ 281, 20140558 (2014)

67. van der Sluijs, J. P. et al. Conclusions of the Worldwide Integrated Assessment on the risks of neonicotinoids and fipronil to biodiversity and ecosystem functioning. Environ. Sci. Pollut. Res. 22, 148-154 (2015).

68. Park, M. G., Blitzer, E. J., Gibbs, J., Losey, J. E. \& Danforth, B. N. Negative effects of pesticides on wild bee communities can be buffered by landscape context. Proc. R. Soc. B 282, 20150299 (2015)

69. Gabriel, D. \& Tscharntke, T. Insect pollinated plants benefit from organic farming. Agric. Ecosyst. Environ. 118, 43-48 (2007).

70. Pisa, L. W. et al. Effects of neonicotinoids and fipronil on non-target invertebrates. Environ. Sci. Pollut. Res 22, 68-102 (2015).

71. Godfray, H. C. J. et al. A restatement of recent advances in the natural science evidence base concerning neonicotinoid insecticides and insect pollinators. Proc. R. Soc. Lond. B 282, 20151821 (2015).

72. Stanley, D. A. et al. Neonicotinoid pesticide exposure impairs crop pollination services provided by bumblebees. Nature 528, 548-550 (2015).

73. Rundlöf, M. et al. Seed coating with a neonicotinoid insecticide negatively affects wild bees. Nature 521, 77-80 (2015).
In a landscape experiment consisting of eight farms paired with controls this study showed that actual field exposure to a neonicotinoid-pyrethroid seed treatment reduced wild bee densities, nesting success, bumblebee colony growth and reproduction, but did not measurably affect honeybee colony strength.

74. Gill, R. J., Ramos-Rodriguez, O. \& Raine, N. E. Combined pesticide exposure severely affects individual- and colony-level traits in bees. Nature 491, 105-108 (2012).

75. Woodcock, B. A. et al. Impacts of neonicotinoid use on long-term population changes in wild bees in England. Nat. Commun. 7, 12459 (2016).

76. Fischer, D. \& Moriarty, T. Pesticide Risk Assessment for Pollinators (John Wiley \& Sons, 2014).

77. Cross, P. Pesticide hazard trends in orchard fruit production in Great Britain from 1992 to 2008: a time-series analysis. Pest Manag. Sci. 69, 768-774 (2013).

78. Ekström, G. \& Ekbom, B. Pest control in agro-ecosystems: an ecological approach. Crit. Rev. Plant Sci. 30, 74-94 (2011).

79. Johansen, E., Hooven, L. A. \& Sagili, R. R. How to Reduce Bee Poisoning from Pesticides (Oregon State Univ. Extension Service, 2013).

80. Waddington, H. et al. Farmer field schools for improving farming practices and farmer outcomes in low- and middle-income countries: a systematic review. Campbell Syst. Rev. 10, 1-335 (2014).

81. Barzman, M. \& Dachbrodt-Saaydeh, S. Comparative analysis of pesticide action plans in five European countries. Pest Manag. Sci. 67, 1481-1485 (2011).

82. Ekström, G. \& Ekbom, B. Can the IOMC revive the 'FAO code' and take stakeholder initiatives to the developing world? Outlooks Pest Manag. 21, 125-131 (2010).

83. Mommaerts, V., Jans, K. \& Smagghe, G. Impact of Bacillus thuringiensis strains on survival, reproduction and foraging behaviour in bumblebees (Bombus terrestris). Pest Manag. Sci. 66, 520-525 (2010).

84. Bohan, D. A. et al. Effects on weed and invertebrate abundance and diversity of herbicide management in genetically modified herbicide-tolerant winter-sown oilseed rape. Proc. R. Soc. B 272, 463-474 (2005).

85. Marvier, M., McCreedy, C., Regetz, J. \& Kareiva, P. A meta-analysis of effects of Bt cotton and maize on nontarget invertebrates. Science 316, 1475-1477 (2007).

86. Lu, Y. et al. Mirid bug outbreaks in multiple crops correlated with wide-scale adoption of Bt cotton in China. Science 328, 1151-1154 (2010).

87. Barfoot, P. \& Brookes, G. Key global environmental impacts of genetically modified (GM) crop use 1996-2012. GM Crops Food 5, 149-160 (2014).

88. Andow, D. A. et al. An ecologically-based method for selecting ecological indicators for assessing risks to biological diversity from geneticallyengineered plants. J. Biosaf. 22, 141-156 (2013).

89. Wilfert, L. et al. Deformed wing virus is a recent global epidemic in honeybees driven by Varroa mites. Science 351, 594-597 (2016).

90. Moritz, R. F. A., Härtel, S. \& Neumann, P. Global invasions of the western honeybee (Apis mellifera) and the consequences for biodiversity. Ecoscience 12, 289-301 (2005)

91. Dohzono, I. \& Yokoyama, J. Impacts of alien bees on native plant-pollinator relationships: a review with special emphasis on plant reproduction. Appl. Entomol. Zool. (Jpn.) 45, 37-47 (2010).

92. Fürst, M. A., McMahon, D. P., Osborne, J. L., Paxton, R. J. \& Brown, M. J. F. Disease associations between honeybees and bumblebees as a threat to wild pollinators. Nature 506, 364-366 (2014).

This paper sampled Apis and Bombus across 26 geographically dispersed sites in the United Kingdom revealing the co-prevalence of deformed wing virus (DWV) infections and evidence of local transmission, suggesting disease spill-over from managed honeybees to wild bumblebee species.

93. Tehel, A., Brown, M. J. F. \& Paxton, R. J. Impact of managed honey bee viruses on wild bees. Curr. Opin. Virol. 19, 16-22 (2016).

94. Quezada-Euán, J. J. G., de Jesús May-Itzá, W. \& González-Acereto, J. A. Meliponiculture in México: problems and perspective for development. Bee World 82, 160-167 (2001).

95. Cook, D. C., Thomas, M. B., Cunningham, S. A., Anderson, D. L. \& De Barro, P. J. Predicting the economic impact of an invasive species on an ecosystem service. Ecol. Appl. 17, 1832-1840 (2007).

96. Hunter, W. et al. Large-scale field application of RNAi technology reducing Israeli acute paralysis virus disease in honey bees (Apis mellifera, Hymenoptera: Apidae). PLoS Pathogens 6, e1001160 (2010).

97. Hanna, C., Foote, D. \& Kremen, C. Invasive species management restores a plant-pollinator mutualism in Hawaii. J. Appl. Ecol. 50, 147-155 (2013).

98. Traveset, A. \& Richardson, D. M. Mutualistic interactions and biological invasions. Annu. Rev. Ecol. Evol. Syst. 45, 89-113 (2014).

99. Morales, C. L., Arbetman, M. P., Cameron, S. A. \& Aizen, M. A. Rapid ecological replacement of a native bumble bee by invasive species. Front. Ecol. Environ 11, 529-534 (2013).

100. Sáez, A., Morales, C. L., Ramos, L. Y. \& Aizen, M. A. Extremely frequent bee visits increase pollen deposition but reduce drupelet set in raspberry. J. Appl. Ecol. 51, 1603-1612 (2014).

101. Settele, J. et al. in Climate Change 2014: Impacts, Adaptation, and Vulnerability (eds Field, C. B. et al.) 271-359 (Cambridge Univ. Press, 2014).

102. Hegland, S. J., Nielsen, A., Lázaro, A., Bjerknes, A. L. \& Totland, Ø. How does climate warming affect plant-pollinator interactions? Ecol. Lett. 12, 184-195 (2009). 
103. Chen, I.-C., Hill, J. K., Ohlemüller, R., Roy, D. B. \& Thomas, C. D. Rapid range shifts of species associated with high levels of climate warming. Science 333, 1024-1026 (2011).

104. Schweiger, O., Settele, J., Kudrna, O., Klotz, S. \& Kühn, I. Climate change can cause spatial mismatch of trophically interacting species. Ecology $\mathbf{8 9}$, 3472-3479 (2008).

105. Giannini, T. C. et al. Identifying the areas to preserve passion fruit pollination service in Brazilian Tropical Savannas under climate change. Agric. Ecosyst. Environ. 171, 39-46 (2013).

106. Polce, $\mathrm{C}$ et al. Climate-driven spatial mismatches between British orchards and their pollinators: increased risks of pollination deficits. Glob. Change Biol. 20, 2815-2828 (2014).

107. Settele, J., Bishop, J. \& Potts, S. G. Climate change impacts on pollination. Nat. Plants 2, 16092 (2016)

108. Forister, M. L. et al. Compounded effects of climate change and habitat alteration shift patterns of butterfly diversity. Proc. Natl Acad. Sci. USA 107 2088-2092 (2010).

109. Warren, M. S. et al. Rapid responses of British butterflies to opposing forces of climate and habitat change. Nature 414, 65-69 (2001).

110. Burton, I. \& Lim, B. Achieving adequate adaptation in agriculture. Clim. Change 70, 191-200 (2005).

111. Frimpong, E. A., Gemmill-Herren, B., Gordon, I. \& Kwapong, P. K. Dynamics of insect pollinators as influenced by cocoa production systems in Ghana. J. Pollinat. Ecol. 5, 74-80 (2011).

112. Kremen, C. \& Miles, A. Ecosystem services in biologically diversified versus conventional farming systems: benefits, externalities, and trade-offs. Ecol. Soc. 17,40 (2012)

113. Arias-Cóyotl, E., Stoner, K. E. \& Casas, A. Effectiveness of bats as pollinators of Stenocereus stellatus (Cactaceae) in wild, managed in situ, and cultivated populations in La Mixteca Baja, central Mexico. Am. J. Bot. 93, 1675-1683 (2006).

114. Padoch, C. \& Pinedo-Vasquez, M. Saving slash-and-burn to save biodiversity. Biotropica 42, 550-552 (2010).

115. Zizumbo-Villarreal, D., Vargas-Ponce, O., Rosales-Adame, J. J. \& ColungaGarcíaMarín, P. Sustainability of the traditional management of Agave genetic resources in the elaboration of mezcal and tequila spirits in western Mexico. Genet. Resour. Crop Evol. 60, 33-47 (2013).

116. Hernandez, J. L., Frankie, G. W. \& Thorp, R. W. Ecology of urban bees: a review of current knowledge and directions for future study. Cities Environ. 2, 3 (2009).

117. Lopes, A. V., Girão, L. C., Santos, B. A., Peres, C. A. \& Tabarelli, M. Long-term erosion of tree reproductive trait diversity in edge-dominated Atlantic forest fragments. Biol. Conserv. 142, 1154-1165 (2009).

118. Berg, Å., Ahrné, K., Öckinger, E., Svensson, R. \& Wissman, J. Butterflies in semi-natural pastures and power-line corridors - effects of flower richness, management, and structural vegetation characteristics. Insect Conserv. Divers. 6, 639-657 (2013).

119. Van Geert, A., Van Rossum, F. \& Triest, L. Do linear landscape elements in farmland act as biological corridors for pollen dispersal? J. Ecol. 98, 178-187 (2010).

120. Kormann, U. et al. Corridors restore animal-mediated pollination in fragmented tropical forest landscapes. Proc. R. Soc. B 283, 20152347 (2016).

Acknowledgements We thank Y. Estrada for preparing the figures and the authors of the original articles for providing the data that underpin them. We are grateful to the authors and reviewers of ref. 5 for their contributions to the report.

Author Contributions All authors contributed equally to the planning, evaluation of the literature and writing of the manuscript.

Author Information Reprints and permissions information is available at www.nature.com/reprints. The authors declare no competing financial interests. Readers are welcome to comment on the online version of the paper. Correspondence and requests for materials should be addressed to S.G.P (s.g.potts@reading.ac.uk).

Reviewer Information Nature thanks R. Gill, R. Paxton and N. Raine for their contribution to the peer review of this work. 